\title{
MEKANISME PENDISTRIBUSIAN PRODUK TELKOMSEL KEPADA KONSUMEN MELALUI PT. TELESINDO SHOP DI KOTA SORONG
}

\author{
Rais Dera Pua Rawi ${ }^{1}$, Lestari Aprilia ${ }^{2}$ \\ ${ }^{12}$ Program Studi Manajemen, Universitas Muhammadiyah Sorong \\ Email : raisdera207@gmail.com
}

\begin{abstract}
Abstrak
Tujuan dari pelaksanaan pengabdian ini adalah untuk memberikan informasi secara komprehensif tentang mekanisme pendistribusian produk telkomsel kepada konsumen. Penelitian ini menggunakan penelitian kualitatif. Penelitian ini mengunakan tiga pendekatan yaitu observasi, wawancara dan dokumentasi. Jenis penelitian yang dipakai oleh penulis adalah penelitian kualitatif deskriptif. Teknik Analisis data hanya sampai pada taraf deskripsi, yaitu menganalisis dan menyajikan data secara sistematik dalam wujud kata-kata, kalimat, atau paragraf yang dinyatakan dalam bentuk narasi sehingga lebih mudah untuk dipahami. Sumber data yang digunakan berasal dari data primer dan data sekunder. Hasil penelitian menjelaskan bahwa diperoleh bahwa strategi yang digunakan dalam memasarkan produk Telkomsel di Kota Sorong yaitu dengan Custommer Service. Dengan memberikan pelayanan terbaik kepada konsumen maka perusahaan dapat berkembang dengan baik. Berdasarkan kegiatan pengabdian yang telah dilakukan maka sebagai kesimpulan bahwa perusahaan PT. Telesindo Shop merupakan perusahaan yang melayani orderan pulsa, penjualan pulsa elektrik maupun data serta penjualan perdana.
\end{abstract}

Kata Kunci : Mekanisme Pendistribusian, Produk Telkomsel, Konsumen

\section{Pendahuluan}

Perkembangan teknologi merupakan salah satu upaya yang sangat diandalkan perusahaan untuk penyelenggaraan aktivitas perusahaan. Peralihan ke sistem elektronik memungkinkan data yang kompleks dapat diproses secara cepat dan teliti, guna menghasilkan suatu informasi. Informasi sangat penting dalam 
mendukung aktivitas perusahaan dalam rangka perkembangan perusahaan itu tersebut.

Pengunaan sistem yang terkomputerisasi ini, bisa saja terdapat banyak kendala dan masalah yang dapat terjadi sejalan dengan proses pemakaian sistem tersebut. Masalah tersebut bermacam-macam, misalnya kehilangan data atau pengambilan keputusan yang salah dikarenakan kesalahan-kesalahan informasi yang diterima. Hal ini dapat terjadi apabila kurangnya pengendalian terhadap sistem informasi, baik pengendalian secara aplikasi maupun umum.

PT. Telesindo Shop merupakan salah satu perusahaan yang bergerak pada bidang telekomunikasi selular. Kegiatan utama perusahaan ini yaitu mendistribusikan produk-produk operator selular dan produk-produk handset selular milik Telkomsel. Karena kegiatan tersebut, dibutuhkan sebuah sistem penjualan yang tepat agar perusahaan selalu dapat memenuhi permintaan akan produk. Pentingnya evaluasi audit dalam dunia usaha serta pentingnya peranan fungsi penjualan pada perusahaan.

Berdasarkan uraian diatas dapat dijelaskan bahwa mekanisme pendistribusian produk telkomsel merupakan suatu masalah yang sangat serius karena tidak hanya dapat berakibat buruk bagi perusahaan, tetapi juga menimbulkan pengaruh yang sangat besar terhadap masyarakat umum. Adapun tujuan dilaksanakan adalah untuk mengetahui mekanisme pendistribusian produk telkomsel kepada konsumen melalui PT Telesindo Shop Di Kota Sorong.

\section{Metode Penelitian}

Penelitian ini mengunakan tiga pendekatan yaitu observasi, wawancara dan dokumentasi. Jenis penelitian yang dipakai oleh penulis adalah penelitian kualitatif deskriptif. Teknik Analisis data hanya sampai pada taraf deskripsi, yaitu menganalisis dan menyajikan data secara sistematik dalam wujud kata-kata, kalimat, atau paragraf yang dinyatakan dalam bentuk narasi sehingga lebih mudah untuk dipahami. 


\section{Hasil Dan Pembahasan}

\section{Bidang Kerja}

Pada saat melaksanakan pengabdian yang ditempatkan di Divisi Telesindo Sales Agent (TSA). Divisi ini merupakan bagian yang penting dalam perusahaan karena merupakan salah satu aset pemasukan dan juga pengenalan produk Telkomsel kepada masyarakat. PT Telesindo Shop merupakan perusahaan yang berfungsi untuk melakukan penjualan pulsa dan perdana serta mengelola data para pelanggan Telkomsel. PT Telesindo Shop dirancang sesuai dengan kebutuhan untuk kepentingan masyarakat yang menggunakan produk-produk Telkomsel, seperti melakukan pengisian pulsa ulang, penjualan perdana serta mengejar target yang telah diberikan oleh atasan.

\section{Pelaksanaan Kerja Menjual Pulsa}

Dalam pengorderan pulsa, pelanggan diarahkan pada Custommer Service (CS), dan disana pelanggan akan dilayani dalam prosedur yang diterapkan perusahaan yaitu dengan menggunakan system 3S (Senyum, Salam, dan Sapa). Dalam bagian ini pelanggan juga dapat bertanya-tanya tentang masalah produk, seperti bagaimana cara membuka pemblokiran M-Kios, promo yang sedang berlangsung, dan lain sebagainya. Untuk tugas TSA yang berhubungan langsung dengan pelanggan yaitu menawarkan pengisian pulsa. Karena itu kenapa PT. Telesindo membuka stand resmi seperti di Bandara, Pelabuhan, dan juga di Mall yaitu guna mempermudah kebutuhan pelanggan yang terjadi secara tiba-tiba. 


\section{Menjual Paket Data}

Selain menjual pulsa elektrik, TSA juga dapat menjual paket data sesuai keinginan pelanggan. Ada juga tersedia paket data combo. Paket data combo yaitu paket data yang kuota internetnya lebih besar disertai bonus Telpon serta SMS dengan harga yang sangat terjangkau. TSA wajib menawarkan paket data combo kepada pelanggan apabila nomor pelanggan terdapat promo combo tersebut.

\section{Menjual Perdana Segel Dan Paket}

TSA juga di sediakan perdana segel dan juga perdana paket untuk ditawarkan kepada pelanggan. Perdana segel yaitu perdana biasa yang didalamnya hanya ada pulsa biasa sedangkan perdana paket yaitu perdana yang didalamnya sudah diisi paket internet.

\section{Menawarkan Aplikasi Bawaan Telkomsel}

Maksud dari aplikasi bawaan Telkomsel yaitu Aplikasi yang dibuat atau yang telah bekerja sama dengan Telkomsel. Aplikasi yang dimaksud antara lain Viu, Hooq, Maxstream, Langit Music, Link Aja, dan lain-lain.

\section{Menukarkan Poin Pelanggan}

Pelanggan berhak menukarkan poin apabila telah memenuhi syarat yang telah ditentukan oleh Perusahaan, seperti membeli pulsa paket data dan yang lebih utama yaitu mempunyai poin yang cukup untuk ditukarkan dengan barang yang diinginkan pelanggan. 


\section{Melaporkan Kegiatan Dan Juga Penjualan}

Setelah selesai mengerjakan tugas sebagai TSA, TSA wajib melaporkan kegiatan dan juga penjualan, seperti mencatat pulsa apa saja yang terjual dan berapa penjualan yang telah dicapai lalu dikirim ke grup line TSA Telesindo.

\section{Mendokumentasikan Kegiatan}

Setiap baru memulai kegiatan TSA wajib mendokumentasikan kegiatan, guna sebagai bukti bahwa TSA benar-benar kerja pada hari dan tanggal tersebut. Minimal foto yang digunakan yaitu 4 gambar serta di grid dan diberi catatan hari, tanggal, tempat tugas, dan siapa yang bertugas. Setelah digrid gambar tersebut dikirim di grup line TSA Telesindo.

\section{Mengejar Target Yang Telah Diberikan}

Setiap TSA yang bertugas masing-masing sudah diberi target oleh atasan, dan TSA wajib memenuhi target tersebut. Target yang dimaksud seperti penjualan, menawarkan serta mendaftarkan aplikasi bawaan Telkomsel yang akan menambah revenue Perusahaan.

\section{Kendala-Kendala Yang Di Hadapi}

Selama dua bulan praktikan melaksanakan Praktek Kerja Lapangan (Magang) di PT. Telesindo Shop, penulis mendapatkan beberapa kendala. Kendala yang dihadapi praktikan adalah sebagai berikut : 1) Mendapat pelanggan yang tidak bertanggung jawab,( Setiap manusia mempunyai watak dan sifat yang berbeda, melalui pengalaman yang penulis dapatkan ada pelanggan yang tidak berkomitmen. Contohnya awal percakapan pelanggan meminta pulsa 50.000 biasa setelah TSA sudah mengisi pulsa tersebut tiba-tiba pelanggan merubah permintaannya dan tidak mau membayar pulsa yang sudah 
terisi). Penyelesaiannya : Lewat pengalaman yang penulis alami setelah perdebatan panjang dan diberikan pengertian sesuai yang sudah terjadi, pelanggan tetap bersikeras tidak mau membayar. Dan TSA lah yang menombok pulsa yang sudah keluar tersebut. 2) Cuaca yang tidak menentu karena bertugas di lapangan, ( Karena bertugas dilapangan jadi kita tidak bisa tau cuaca yang tiba-tiba berubah, sehingga ada saja kendala yang terjadi seperti kehujanan. Penyelesaiannya : Sebelum bertugas sebaiknya menyiapkan segala persiapan sehingga meminimalisir kendala-kendala yang terjadi. 3) Jaringan yang tiba-tiba hilang atau loading lama yang mengakibatkan terhambatnya transaksi. Bagi para penjual pulsa masalah jaringan yang tiba-tiba hilang adalah hal biasa, yang tidak biasa yaitu tidak ada informasi ke penjual pulsa dari pihak jaringan dan menyebabkan pelanggan yang tiba-tiba komplain. Penyelesaiannya, Memberikan pengertian kepada pelanggan secara baik-baik agar pelanggan tersebut mengerti bahwa butuh waktu beberapa menit dikarenakan terkendalanya jaringan yang menjadi penghambat dalam pengisian pulsa.

\section{Kesimpulan dan Implementasi}

Berdasarkan kegiatan pengabdian yang telah dilakukan maka sebagai kesimpulan bahwa perusahaan PT. Telesindo Shop merupakan perusahaan yang melayani orderan pulsa, penjualan pulsa elektrik maupun data serta penjualan perdana.

Selain membuka orderan pulsa PT. Telesindo Shop juga membuka stand untuk memasarkan produk mereka, seperti di Bandara, Pelabuhan, ataupun di Mall. Dari hasil penelitian diperoleh bahwa strategi yang digunakan dalam 
memasarkan produk Telkomsel di Kota Sorong yaitu dengan Custommer Service. Dengan memberikan pelayanan terbaik kepada konsumen maka perusahaan dapat berkembang dengan baik.

\section{Daftar Pustaka}

McLeod Raymond dan George P. Schell. 2007. Sistem Informasi Manajemen. Edisi 9.Terjemahan : Heri Yulianto. Jakarta: Indeks

http://sisteminformasi.wordpress.com/2007/01/22/sistem-informasi. Diakses tanggal 21 April 2012

http://id.wikipedia.org/wiki/PHP. Diakses tanggal 20 Mei 2012

http://yssoft.web.id/keistimewaan-mysql. Diakses tanggal 20 Mei 2012

Sumber: http://swa.co.id

https://telesindo.wordpress.com/hengky-setiawan-pemilik-telesindo-si-rajapulsa/

https://www.maxmanroe.com/vid/marketing/pengertian-distribusi.html

http://seputar pengertian.blogspot.com/2017/06/pengertian-penjualan-serta-jenis-dantujuannya.html

M. Tohar. 2000. Membuka Usaha Kecil. Kanisius: Yogyakarta.

https://pengertian ahli.id/2014/05/pengertian-produk-dan-jenis-produk.html 
8| P a g e 